\title{
Experiences of social work students with learning theoretical knowledge in constructivist higher vocational education: a qualitative exploration
}

Citation for published version (APA):

Van Bommel, M., Kwakman, K., \& Boshuizen, E. (2012). Experiences of social work students with learning theoretical knowledge in constructivist higher vocational education: a qualitative exploration. Journal of Vocational Education \& Training, 64(4), 529-542. https://doi.org/10.1080/13636820.2012.727857

DOI:

10.1080/13636820.2012.727857

Document status and date:

Published: 01/12/2012

Document Version:

Peer reviewed version

Document license:

CC BY-NC-ND

Please check the document version of this publication:

- A submitted manuscript is the version of the article upon submission and before peer-review. There can be important differences between the submitted version and the official published version of record. People interested in the research are advised to contact the author for the final version of the publication, or visit the DOI to the publisher's website.

- The final author version and the galley proof are versions of the publication after peer review.

- The final published version features the final layout of the paper including the volume, issue and page numbers.

Link to publication

\section{General rights}

Copyright and moral rights for the publications made accessible in the public portal are retained by the authors and/or other copyright owners and it is a condition of accessing publications that users recognise and abide by the legal requirements associated with these rights.

- Users may download and print one copy of any publication from the public portal for the purpose of private study or research.

- You may not further distribute the material or use it for any profit-making activity or commercial gain

- You may freely distribute the URL identifying the publication in the public portal.

If the publication is distributed under the terms of Article $25 \mathrm{fa}$ of the Dutch Copyright Act, indicated by the "Taverne" license above, please follow below link for the End User Agreement:

https://www.ou.nl/taverne-agreement

Take down policy

If you believe that this document breaches copyright please contact us at:

pure-support@ou.nl

providing details and we will investigate your claim.

Downloaded from https://research.ou.nl/ on date: 26 Apr. 2023 


\section{Experiences of social work students with learning theoretical knowledge in constructivist higher vocational education: a qualitative exploration}

Marijke van Bommel, Kitty Kwakman, and Henny P.A. Boshuizen

\section{Citation}

van Bommel, M., Kwakman, K., \& Boshuizen, H. P. A. (2012). Experiences of social work students with learning theoretical knowledge in constructivist higher vocational education: a qualitative exploration. Journal of Vocational Education \& Training, 64(4), 529-542.

Keywords

higher vocational education . body of knowledge . authentic learning . contexts; self-directed learning . social work 


\begin{abstract}
An important learning goal in higher vocational education concerns the professional domain's shared body of knowledge. Constructivist programmes use authentic learning contexts and self-directed learning to create a close connection throughout the learning process between theoretical knowledge and other forms of professional knowledge. Critics of constructivist learning contend that the situated way of learning places too much emphasis on the instrumental use of knowledge and that self-directed learning is too demanding for students. This qualitative case study investigated these criticisms by exploring the learning experiences of 18 final-year bachelor's students in social work in a constructivist programme. From a previous study, the differences between these participants' theoretical knowledge were known. Results show that while all students agreed that their constructivist programme was beneficial for learning knowledge pertaining to instrumental use, they had different experiences with acquiring knowledge as a system of meaning in itself. Students with high-level knowledge felt positively challenged and actively studied theories as a whole. Students with medium- and low-level knowledge had not reached beyond the knowledge that was immediately needed in the authentic learning contexts. Hypotheses and questions for further research into differences between students are discussed.
\end{abstract}




\section{Introduction}

An important learning goal in higher vocational education concerns the shared body of knowledge of a student's future professional domain. This body of knowledge consists of theoretical knowledge: facts, concepts, principles and theories (Novak 2010). A professional in a specific domain needs theoretical knowledge to understand what happens and why, to take informed decisions about actions and to account for choices and results (Eraut 1994). Theoretical knowledge (know what and why), however, is not the only form of professional knowledge (Tynjälä 2009). Other equally important forms of knowledge are practical/experiential knowledge residing in skills (know how), regulative knowledge (know when and who) and sociocultural knowledge (prescribed conditions and procedures). To become competent practitioners, students need to integrate all these forms of professional knowledge. Social work programmes in many countries use educational designs that, throughout the learning process, connect theoretical knowledge to the other forms of professional knowledge. These designs include project-based learning, problem-based learning and, more recently, competency-based learning. All of these designs are based on a constructivist approach that views learning as an active and cooperative process of knowledge construction situated in meaningful contexts (Lave and Wenger 1991; Tobias and Duffy 2009; Van Merriënboer 1997). As part of this process, students must also learn how to direct their learning process in preparation for lifelong learning (Field 2006; Simons, Van der Linden, and Duffy 2000). Both the situated ways of learning and the focus on self-directed learning are criticised for having undesirable effects on learning theoretical knowledge. A first criticism is about what students learn. It states that students do not learn enough knowledge to cover the domain body of knowledge, but merely learn skills to find information (Van den Berg and De Bruijn 2009). The strong focus on knowledge application is said to inhibit student access to disciplinary knowledge as a system of meaning in itself (Wheelahan 2010). A second criticism is about how students learn. Kirschner, Sweller, and Clark (2006) claim that self-directed learning is too demanding for students and that direct knowledge instruction is wanted. These criticisms are stated as pertaining to all students alike. In a previous study, however, we found strikingly large differences between students. In that study, experts appraised the quality of the theoretical knowledge amassed by final-year students in a constructivist, competency-based social work programme at a Dutch university of applied sciences (Van Bommel, Boshuizen and Kwakman 2012). The appraisals ranged from high to low and showed that authentic contexts and self-directed learning were not equally beneficial for all students. This result led us to explore the learning experiences of the same students to discover more about the differences between them. In this study, we aim to identify factors influencing the learning experiences of different students. In this paper, we examined the following questions:

- How do final-year social work students with different knowledge appraisals describe the extent and depth of their own theoretical knowledge as acquired in a constructivist programme? 
- What are the experiences of these students with authentic learning context and self-directed learning in regard to learning their domain's body of knowledge?

Before we proceed, we need to comment on the social work body of knowledge in the context of our study. In the Netherlands, social work programmes are given by universities of applied sciences. Bachelor's programmes last four years and contain a considerable amount of practice learning in the form of internships. Moreover, unlike other countries, the Netherlands has no academic counterpart for social work at university. The core of the social work body of knowledge is derived from disciplines such as psychology, sociology, psychopathology, pedagogy and philosophy (Sectorraad HSAO 2008). In addition to this generic core, specialised knowledge is available for many different work field contexts and service users. This knowledge includes knowledge of specific service users, their contexts and problems, knowledge of intervention approaches, methods and evidence of their effectiveness; and knowledge of societal and organisational work conditions, including economic resources, legislation, policies and protocols (Cosis Brown 1996).

\section{Theoretical background}

\section{The social work body of knowledge and professional practice}

Professionals need theoretical knowledge to do their tasks well and account for them, and to critically examine practice (Edwards 1998). In the domain of social work, applying theoretical knowledge is not straightforward. Social work is an ill-structured domain characterised by complex, highly specific cases and multiple dilemmas (Parton and O'Byrne 2000; Van Ewijk 2010). For this reason, the social work body of knowledge does not offer single, prescriptive solutions or guaranteed success of interventions. Instead, it provides tools for analysing and interpreting situations, for choosing interventions, for evaluating outcomes and for accounting for one's actions (Eraut 1994; Otto, Polutta, and Ziegler 2009; Parton and O'Byrne 2000; Van Ewijk 2010). Using theoretical knowledge to cope with dilemmas and to critically examine practice requires the ability to question daily practice, routines, protocols and work conditions from multiple perspectives. Edwards (1998) mentions the important role of language: every perspective (service user, academic, professional, manager and politician) has their own way of discoursing about practice. According to Foucault (1980), these discourses differ as to power. More powerful, ruling discourses can define, for example, what is considered normal and what is considered problematic, and can impose this meaning on others. Social workers operate between different discourses and have to deal with different, often conflicting interests of service users, organisations and society (Irving 2009). To critically examine practice, social workers need the ability to discover differences in meanings between discourses and to negotiate and translate between them (Edwards 1998). This allows practitioners to competently combine care and control and to confront dilemmas between individual rights and community demands in areas such as childcare, probation work, community work or forensic psychiatry. Further, as Ball (2008) points out, this ability permits practitioners to cope with the growing demands of accountability imposed by the adoption of market and managerial concepts in the public sector at the cost of time for working with service users. 
In an ill-structured domain like social work, solutions to problems are never simple. Spiro and DeSchryver (2009) contend that in an ill-structured domain professionals need to assemble tailor-made solutions for unique problems by combining knowledge elements in novel ways in many different authentic contexts. This is an active, essentially constructive and personal process that changes both the knowledge and the learner (Eraut 1994; Hager and Hodkinson 2009; Spiro and DeSchryver 2009). This process requires understanding the complexity of practical situations and coping with one's own personal possibilities and limitations. Constructivist learning theory offers explanations for how such learning is brought about.

\section{Learning theoretical knowledge according to constructivist learning theory}

Constructivist learning theory is based on several older learning theories such as activation of prior knowledge (Ausubel 1963); learning through activity, experience and reflection (Bruner 1966; Piaget 1972); using social environments for cooperation and discourse, and for support by teachers or more capable peers (Vygotski 1978); and situated learning in authentic contexts (Lave and Wenger 1991). In a constructivist programme, theoretical knowledge is learned in the context of performing authentic whole tasks in real-life circumstances including teamwork and cooperation with other professions. Knowledge learning support is embedded in these authentic contexts instead of existing as separate courses for academic disciplines. In lectures, relevant disciplinary knowledge is instructed justin-time (Van Merriënboer 1997). Other activities are classroom discussions and consultations of content experts, both of which are supplemented by literature suggestions, library and ICT facilities. Constructivistbased education also demands that students be responsible for their own learning. Self-directed learning is stimulated by progressively diminishing teacher direction and supported by training cognitive and regulative learning skills such as how to plan, execute, monitor and evaluate one's own learning (Simons, Van der Linden, and Duffy 2000). Developing selfdirected learning requires what Vermunt and Verschaffel (2000) call constructive friction: offering the right amount of challenge for individual students to expand their capabilities and understanding. Demands on the student must be neither too high, which would cause discouragement, nor too low, which would lead to boredom and underachievement. Self-directed learning prepares students for lifelong learning, enabling them to maintain their employability and to contribute to future knowledge development (Bereiter 2002; Field 2006).

\section{Critiques of constructivist learning}

The constructivist way of supporting the acquirement of a domain body of knowledge described above has triggered critiques that question situated and self-directed learning. First, educational sociologists have criticised constructivist learning for its contextual and thus instrumental way of learning knowledge, causing knowledge to be 'delocated from the system-of-meaning in which it is embedded' (Wheelahan 2010,127). According to Maton and Moore (2010), knowledge itself has structures that need to be considered in teaching, for example, in establishing the sequencing of knowledge in a curriculum.

Learning knowledge in authentic learning contexts only is not enough, because it denies students access to socially powerful forms of academic knowledge that 
are needed to critically question practice. Second, constructivist learning theory has been called ineffective and inefficient for several reasons including (a) overestimation of students' cognitive abilities and prior

knowledge; (b) lack of direct instruction, which places too much cognitive load on working memory; (c) the time-consuming nature of learning activities and the diversion from focusing on deep understanding caused by practical task aspects, such as collecting data, making a poster and (d) unfeasible demands on the average teacher's knowledge and abilities (Bereiter 2002; Kirschner, Sweller, and Clark 2006; Tobias and Duffy 2009).

\section{Philosophical and epistemological issues}

To better understand constructivist learning theory, we need to examine its place in philosophy and epistemology. Constructivism arose as a reaction to positivism. Positivism sees knowledge as objective and independent of context or persons and learning as acquiring knowledge: the acquisition metaphor (Sfard 1998). Positivist education emphasises instruction by teachers. In contrast, constructivism sees knowledge as relative, changing with historical and cultural context, and as personal: knowledge is a person's interpretation of reality. For a constructivist, knowledge can only partially be agreed upon between people. Constructivism sees learning as building one's knowledge in participation and in dialogue with other people: the participation metaphor (Sfard 1998; Tobias and Duffy 2009). In short, constructivist education emphasises the active role of the learners, which is facilitated by teachers, the learning environment and professional communities. Maton and Moore (2010) criticise both views and state that knowledge should be seen as social and fallible rather than as objective or relative. Bereiter (2002) challenges the constructivist assumption that there is no knowledge apart from the knower. He recognises the situational and social nature of knowledge embedded in cultural practices, but he also sees knowledge as something in itself, which he calls conceptual artefacts: knowledge as a human creation that exists separate from individual minds and that can be described, discussed and improved.

From the above discussions, we conclude that after a period in which the instrumental use of theoretical knowledge was emphasised, current educational and sociological debates reflect a shift towards a stronger focus on the body of knowledge as a goal in itself (Bereiter 2002; Maton and Moore 2010; Wheelahan 2010). Therefore, we included in our analysis Wheelahan's distinction between theoretical knowledge as instrumental vs. theoretical knowledge as a system-ofmeaning.

\section{Method}

The study was designed as an explorative qualitative case study (Yin 2003). Its aim was to contribute to the empirical knowledge of constructivist learning in a real-life setting. Our method was based on the grounded theory approach by Corbin and Strauss (2008) and the qualitative analysis approach of Miles and Huberman (1994). It combined inductive and deductive approaches to access students' real-life experiences from their own perspective and in their own 
language, and to interpret these experiences in the light of constructivist learning theory and its critiques.

\section{Participants}

Participants were 18 final-year bachelor's students in social work (15 females and 3 males), equally divided over three social work specialisation courses. Purposive sampling was accomplished by asking teachers of each course for names of six students they saw as representative and who were willing to participate. Participants varied in age from 20 to 24 years, except for one participant who was 27-years old. The prior education of eight participants was secondary vocational education, and 10 participants had attended general secondary education. Grade point averages varied from 6.6 to 8.3 on a 10-point scale. In respect to gender, age, prior education and grade point averages, the 18 participants were representative for their year group $(n=205)$. In an earlier study, expert teachers evaluated the quality of the theoretical knowledge of these participants (Van Bommel, Boshuizen and Kwakman 2012). Four qualitative features were appraised: (1) knowledge extent: coverage of relevant facts, factors and actors; (2) knowledge depth: coverage of multiple theoretical perspectives and multiple work levels (interpersonal, organisational and societal); (3) knowledge structure: completeness and conciseness and reciprocal/systemic vs. simple/linear interconnections and (4) critical control: explicit use of theoretical concepts vs. informal language. Based on their appraisals, the participants were classified into four groups: Group H (high level, $\mathrm{n}=4$ ), which received high appraisals on all four features; Group HM (mixed high/medium level, $n=2$ ), which received high appraisals for knowledge extent and depth, and medium appraisals for structure and critical control; Group M (medium level, $\mathrm{n}=7$ ), which received medium appraisals for knowledge extent and depth, and medium to low appraisals for structure and critical control; and Group L (low level, $n=5$ ), which received low appraisals on all knowledge features. The height of the students' levels showed no correlations with their grade point averages or with their prior education (general vs. vocational secondary education).

Table 1. Overview of participants' appraisals.

\begin{tabular}{|c|c|c|c|c|c|c|}
\hline & & $\begin{array}{l}\text { Apprai } \\
\text { knowle }\end{array}$ & on feat & of theoreti & & \\
\hline $\begin{array}{l}\text { Group of } \\
\text { participants }\end{array}$ & $\mathrm{n}$ & Extent & Depth & Structure & $\begin{array}{l}\text { Critical } \\
\text { Control }\end{array}$ & $\begin{array}{l}\text { Use of } \\
\text { formal } \\
\text { language }\end{array}$ \\
\hline High-level & 4 & $\mathrm{H}$ & $\mathrm{H}$ & $\mathrm{H}$ & $\mathrm{H}$ & $\mathrm{M}$ \\
\hline $\begin{array}{l}\text { High- } \\
\text { /medium } \\
\text { level }\end{array}$ & 2 & $\mathrm{H}$ & $\mathrm{H}$ & $M$ & $M$ & $M$ \\
\hline $\begin{array}{l}\text { Medium- } \\
\text { level }\end{array}$ & 7 & $\mathrm{H} / \mathrm{M}$ & M & $\mathrm{L}$ & $\mathrm{L}$ & $\mathrm{L}$ \\
\hline Low-level & 5 & $\mathrm{~L}$ & $\mathrm{~L}$ & $\mathrm{~L}$ & $\mathrm{~L}$ & $\mathrm{~L}$ \\
\hline
\end{tabular}

Note: $\mathrm{H}=$ high appraisal, $\mathrm{M}=$ medium appraisal and $\mathrm{L}=$ low appraisal. 
Table 1 summarises the qualitative appraisals of the participants' theoretical knowledge. From these appraisals, we concluded that knowledge structure and critical control were the most difficult qualities for students to acquire, as only the high-level group did well on these features. The low scores on critical control were due to informal rather than professional language; all students described part of their theoretical knowledge in an implicit manner.

\section{Instruments}

The first instrument was a non-directive interview (Rubin and Rubin 2005).The two main interview questions were (1) 'What do you think of the extent and depth of your own theoretical knowledge that you acquired throughout your programme?' and (2) 'What elements in your programme have helped or hindered you in learning this theoretical knowledge?' During the interview, a second instrument was used: a domain knowledge list with an overview of knowledge topics in social work. The domain knowledge list was composed with content from different sources (Adams, Dominelli, and Payne 2002; Beckett 2006; Cosis Brown 1996; Osmond 2005; Trevethick 2008). The content of the domain knowledge list was validated by experts from social work education (13 senior teachers) and social work practice (20 experts from different social work fields).

\section{Procedures}

One of the researchers interviewed all 18 students individually. Each interview consisted of three parts in a fixed order: (1) discussing the two main questions, (2) marking the knowledge list and (3) reflecting on the marked knowledge list. During part 1 of the interview, a non-judgmental atmosphere was created to invite participants to give honest answers. The interviewer promised anonymity, expressed a sincere curiosity in the participants' experiences and points of view, restrained from judgmental remarks and encouraged participants to elaborate on their answers by probing and asking follow-up questions (Rubin and Rubin 2005).

\begin{tabular}{|c|c|}
\hline & SOCIAL WORK KENNISBASIS \\
\hline \begin{tabular}{l|} 
Cliènt / klant \\
en context
\end{tabular} & 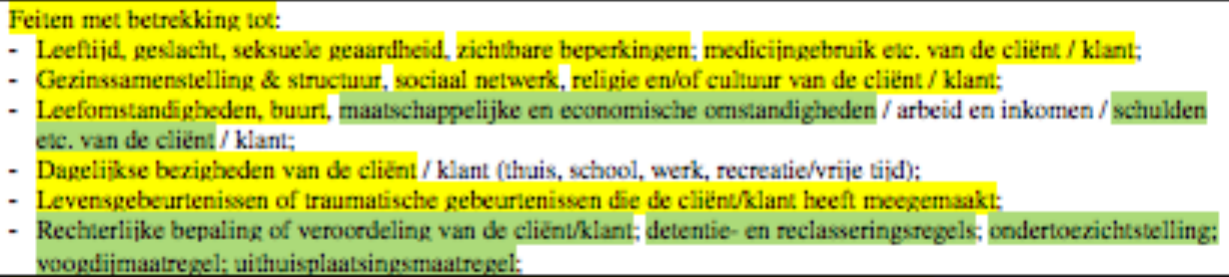 \\
\hline & $\begin{array}{l}\text { Ontwikkelstadia in de (normale) menselijke psychologische, cognitieve, lichamelijke \& } \\
\text { persoonlikkheidsontwikkeling; }\end{array}$ \\
\hline & Hechting; socialisatie; invloed van leeftidgenoten; genogram; scheiling en verlies / omgaan met verandering; \\
\hline & $\begin{array}{l}\text { Percepties en emoties (stress; boosheid; verúliet; depeessie, eenzasmheid; blijdschap); manieren on deze emoties } \\
\text { uit te drukken (extravert/introvert); motivatie; }\end{array}$ \\
\hline & Gedrag: gedragspatronen; groepsgedirag; groepsdynamica; stadia in groepsontwikkeling; \\
\hline & 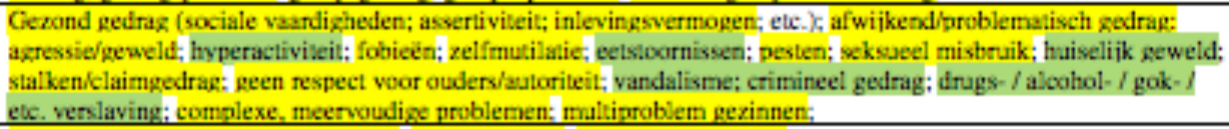 \\
\hline & Mentale of lichamelijke beperkingen; leerproblemen; sociale beperkingen; \\
\hline & Sociale \& culturele omgeving \& participatie / zelfredzaamheid/ zelfzorg: \\
\hline & Armoede: sociale \& economische achterstanden; sociale kwetsbaarheid; sociale / culturele uitsluiting: \\
\hline & $\begin{array}{l}\text { Psychopathologische condities / ziek.es / DSM IV(autisme spectrum stoornissen, ADHD, psychoses, } \\
\text { persoonlijkheidsstoornissen etc.); andere medische condities \& medische risico's; medicijnen \& bijwerkingen; }\end{array}$ \\
\hline
\end{tabular}




\begin{tabular}{|c|c|}
\hline \multicolumn{2}{|r|}{ SOCIAL WORK KENNISBASIS } \\
\hline \multirow[t]{10}{*}{$\begin{array}{l}\text { Cliënt / klant } \\
\text { en context }\end{array}$} & 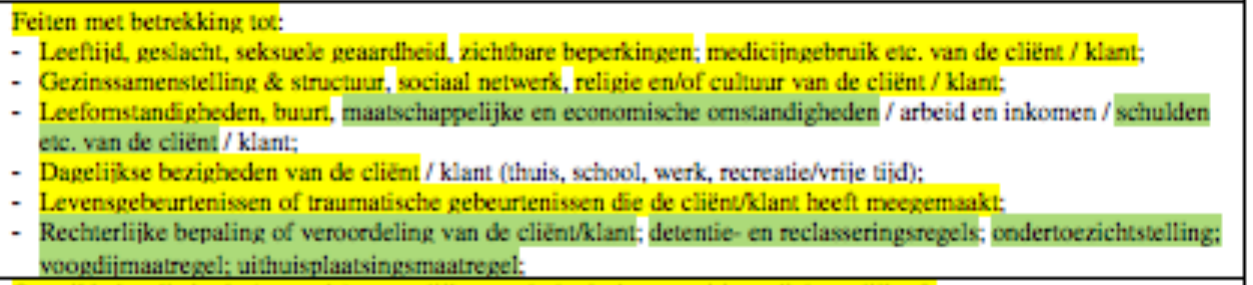 \\
\hline & $\begin{array}{l}\text { Ontwikkelstadia in de (normale) menselijke psychologische, cognitieve, lichamelijke \& } \\
\text { persoonlijkheidsontwikkeling; }\end{array}$ \\
\hline & Hechling; socialisatie: invloed van leeflidgenoten; genogram; scheiching en verlies / omgaan met verandering; \\
\hline & $\begin{array}{l}\text { Percepties en emoties (stress; boosheid; verúriel; depressie, eenzasmheid; blijdschap); manieren on deze emoties } \\
\text { uit te drukken (extravervintrover); motivatie; }\end{array}$ \\
\hline & Cedrag; gedragspatronen; groepsgedraz; groepsdynamica; stadia in groepsontwikkeling; \\
\hline & 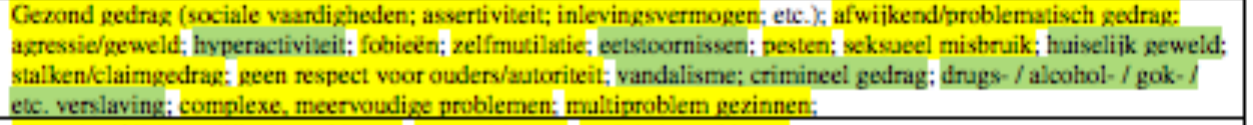 \\
\hline & Mentale of lichamelijke beperkingen; leerproblemen; sociale beperkingen; \\
\hline & Sociale \& culturele omgeving \& participatie / zelfrodzaamheid/ zelfrorg: \\
\hline & Armoede: sociale \& economische achterstanden; sociale kwetsbaarheid, sociale / cullurele uit.Suiting, \\
\hline & $\begin{array}{l}\text { Prychopathologische condities / ziek.es / DSM IV(antisme spectrum stoornissen, ADHD, psychoses, } \\
\text { persoonlijkheidsstbornissen etc.); andere medische condities \& medische risico's; medicijnen \& bijwerkingen; }\end{array}$ \\
\hline \multirow{11}{*}{$\begin{array}{l}\text { Organisatie, } \\
\text { beroep \& } \\
\text { samenleving }\end{array}$} & Het inssellingsbudget, persoonspebonden budget: lokale/nationale financiën en procedures om dere se verkriigen: \\
\hline & 'Sociale kaart' van welzijns/zorg faciliteiten en bulphronnen; \\
\hline & 'Culturele kaart' v. culturele activiteiten, faciliteiten+(financièle) bronnen; \\
\hline & $\begin{array}{l}\text { Wet- en regelgeving (sociasl recht; jeugd \& familierecht; wet op de jeugdrorg; arbeids- \&sociale zekerheidsrecht; } \\
\text { privacyrecht; strafrecht) }\end{array}$ \\
\hline & $\begin{array}{l}\text { Samenwerken / tearnrollen / teambuilding, leiderschapsstijlen / situationeel leiderschap, organisatiecultuur; } \\
\text { intendisciplinaire interactie; vergaderem; onderhandelen; }\end{array}$ \\
\hline & Intervisie, supervisie; collegiale consultatie; zelfsturing en zelfontwikkeling; teamontwikkeling; \\
\hline & Verantwoordelijkheid; kwaliteilszorg; praktijkonderwoek; projectmatig werken; instellingşeleid; ondernemerschap; \\
\hline & (Invloed ven ) Landeliike social-, welziins- en econoenisch beleid op het beroep en de organisatie; \\
\hline & Visies op organisatie \& management: \\
\hline & $\begin{array}{l}\text { Visies op rol, taak en doelstellingen van social woek (care / cure / control), ma en in het verleden; beroepsprofiel; } \\
\text { beroepsethiek: }\end{array}$ \\
\hline & Wereldbeeld, maatschappiivisie; politieke visie; mensentechten en rechten van kinderen; \\
\hline
\end{tabular}

Figure 1. Example of a marked domain knowledge list. 


\begin{tabular}{|c|c|}
\hline \multirow{8}{*}{$\begin{array}{l}\text { Knowledge } \\
\text { about } \\
\text { service } \\
\text { users and } \\
\text { their } \\
\text { contexts }\end{array}$} & $\begin{array}{l}\text { Stages of (normal) human psychological, cognitive, physical \& } \\
\text { personality development; }\end{array}$ \\
\hline & $\begin{array}{l}\text { Attachment; socialization; peer-influence; genogram; separation and } \\
\text { loss; behavior in coping with change; }\end{array}$ \\
\hline & $\begin{array}{l}\text { Perceptions and emotions (stress; anger; grief; depression, loneliness; } \\
\text { happiness); ways of expressing these emotions (extravert / introvert) } \\
\text { motivation; } \\
\text { Behavior ; behavioral patterns; group behavior; group dynamics; stages } \\
\text { in group development }\end{array}$ \\
\hline & $\begin{array}{l}\text { Healthy behavior (social/ interpersonal skills; assertiveness; empathy); } \\
\text { deviant /problematic behavior (aggression / violence; hyperactivity; } \\
\text { phobias; self-mutilation; eating disorders; bullying; sexual abuse; } \\
\text { domestic violence; stalking / claiming; no respect for parents or } \\
\text { authorities; vandalism; criminal behavior); drug, alcohol, gambling an } \\
\text { other. addictions; multi-problem families; d }\end{array}$ \\
\hline & Mental or physical disabilities; learning disabilities; social disabilities; \\
\hline & $\begin{array}{l}\text { Social and cultural environment and participation; abilities of self- } \\
\text { support and self-care; }\end{array}$ \\
\hline & $\begin{array}{l}\text { Poverty; social \& economical deprivations; social vulnerability; social } \\
\text { cultural exclusion; / }\end{array}$ \\
\hline & $\begin{array}{l}\text { Psychopathological conditions / illnesses / DSM IV(autism spectrum } \\
\text { disorders, ADHD, psychosis, personality disorders); other medical } \\
\text { conditions \& medical risks;medicines and side-effects; }\end{array}$ \\
\hline
\end{tabular}

Figure 2. Translation of a fragment of the domain knowledge list in Figure 1.

In part 2 of the interview, participants were given a domain knowledge list and asked to estimate their depth of knowledge for each topic with various colours. Yellow represented 'I know this topic well'; green indicated 'I know this topic, but I would have to look it up to recall it exactly and fully'; and white (unmarked) meant 'I do not know this topic'. This resulted in visual representations of their theoretical knowledge. Figure 1 shows an example of a marked knowledge list. Because the example in Figure 1 is in Dutch, we translated a fragment of the list in Figure 2. The domain knowledge list offered the participants opportunities to leave blanks because, in addition to general topics, it contained highly specialised topics that would be known only to those who had chosen that specialisation during the programme. In part 3, participants were asked to reflect on their own knowledge as it emerged from part 2 with the question: 'What do you think of your own theoretical knowledge when you look at your marked list?'. All interviews were transcribed verbatim.

\section{Analysis}

Analysis was an iterative process of exploring and interpreting, involving three actions; data reduction, data display and conclusion drawing (Miles and Huberman 1994). Each phase of analysis was prepared by one researcher and checked by two other researchers. First, interview transcripts were coded using a predefined coding list as well as open codes emerging from the interviews. The second phase involved interpreting each student's coded quotations. This resulted in individual summaries for several topics (data reduction). In the next phase, student utterances were arranged according to the ranking of their 
previous appraisals. A matrix was then composed (data display) so that the researchers could interpret the outcomes for groups of students with similar appraisals. After making summaries for each group (data reduction), we aggregated this last matrix into a conceptually clustered matrix (data display). The last step was to draw conclusions and verify agreement about them between the three researchers.

\section{Results}

When quoted, participants are distinguished by their ranking (1-18) and subsequent clustering in four groups $(\mathrm{H}=$ high-appraised, $\mathrm{HM}=$ high/mediumappraised, $\mathrm{M}=$ medium-appraised and $\mathrm{L}=$ low-appraised), based on a previous qualitative analysis of their knowledge (see the description of our participants in the method section). Comparison based on other available participant features (age, prior education and grade point averages) did not reveal pattern-like differences and are not included.

\section{Research question 1: perception of own acquired body of knowledge}

All participants tended to underestimate the extent of their own acquired body of knowledge. For example, after marking the domain knowledge list, they expressed surprise at the number of topics they had marked as 'known'. A possible explanation for this lies in their having difficulties in recognising social work knowledge as theoretical knowledge, because of its resemblance with 'daily-life knowledge'(H2 and L14) or with 'acting in a logical way'(M9). Participants from all groups recognised that social work is a broad domain and that their body of knowledge needs to be broad. Because many topics had to be covered, M-group participants expressed uncertainty about the depth of their theoretical knowledge regarding specific subjects and service user groups that they had not worked with in practice (M7, M9, M11 and M13). Participants from the H-group expressed confidence in the depth of their knowledge, because they saw it as transferable to all kinds of cases and contexts. H1: 'I'm confident about my knowledge on behaviour within difficult groups'; H2: 'I've learned to look beyond the surface, what's behind someone's behaviour, so I can find out what really is the matter.'

Throughout the interviews, participants expressed epistemological beliefs about the nature of theoretical knowledge, about the way knowledge is learned and about its value. These beliefs showed differences between the groups ( $\mathrm{H}, \mathrm{HM}, \mathrm{M}$ and L). Participants in the $\mathrm{H}$ - and HM-group emphasised the scientific, objective nature of knowledge, which is 'more reliable than just an opinion' (H2) and is based on scientific research, not just on practical experience' (HM6). H-groupparticipants valued theoretical knowledge not only as instrumental (for working with), but also as 'interesting for its own sake' (H2 and H4). H- and HM-group participants mentioned the effort that is required for learning. Theoretical knowledge must be built 'by critically comparing different sources' (H4) and 'by hard work' (HM5). M-group participants emphasised the instrumental value of theoretical knowledge that is needed to account for one's actions and decisions. They stated that knowledge 'is about the why of things' (M7) and 'for legitimising my actions' (M8 and M12). Theoretical knowledge needs to be 'underpinned by a 
reliable source, a researcher or expert' (M13), but its ultimate worth is revealed in practice: 'I must try it out to see if it works for me' (M12). L-group participants put the instrumental value central; only theoretical knowledge that is connected to practice is 'real' (L14) or 'important' (L16). Theoretical knowledge is 'for making the right choices' (L18), and 'accounting for one's actions' (L14), which, although necessary, 'is a tiring thing to do' (L14).

Research question 2: experiences with authentic learning contexts and self-directed learning

For various reasons, all participants appreciated authentic learning contexts as their preferred way of learning theoretical knowledge. Authentic contexts help to understand and memorise knowledge (H1, H4, M11 and L18), and they enhance interest in knowledge and motivation to learn (H3 and M13). Authentic contexts are especially worthwhile because in social work practice every case is unique (M10 and M8). Recurrence of the same professional tasks at increasingly difficult levels was mentioned as helpful for 'anchoring' and deepening theoretical knowledge (L15 and L17). In these answers, the participants mainly referred to theoretical knowledge as instrumental. For learning theoretical knowledge as a system-of-meaning, authentic contexts led to different experiences. H- and HMgroup participants were inspired to work hard in learning knowledge as a system-of-meaning. 'When I work on a task, I look up many books, so I can compare different views and sources' (H1 and H4); 'I like to dig deep into a subject, by comparing how it is dealt with in different settings' (H3). M- and Lgroup participants reported adverse effects of authentic contexts on learning knowledge as a system-of-meaning. They said they had missed stimuli to study whole books and theories while working on the authentic tasks. 'I picked out of books only what I needed for the task' (L16); 'It costs me a lot of time to understand difficult texts, so I don't read more than necessary' (M10).

The four groups differed in their opinions on the help or hinder caused by the demands of self-directed learning. The experiences described by H- and HMgroup participants revealed a constructive friction. They did not find selfdirected learning easy, but they coped well with it and appreciated the resulting empowerment: 'It wasn't always easy, but it made me strong' (HM6). Both groups showed a strong intrinsic motivation and high ambitions, and described their motivation as a powerful stimulus for learning theoretical knowledge (instrumental and as a system-of-meaning): 'I want to know all there is to know about a subject' (H4). M-group participants experienced a mix of constructive and destructive friction, the former concerning knowledge as instrumental, and the latter concerning knowledge as a system-of-meaning. They expressed a more passive attitude towards learning knowledge as a system-of-meaning, declaring themselves dependent on teachers, peers and the coercive powers of knowledge tests, for example, M11: 'I find it difficult to gain an overview by myself'. L-group participants did not experience constructive friction. They could not cope well with open-ended demands (L14 and L15) and expressed a strong dependence on teacher support and expectations: 'If teachers had made higher demands, I would have worked harder to get a mark beyond the minimum to pass my tests' (L16). L-group participants mentioned that group work also inhibited their selfdirected learning. Under time pressure, L-group participants abandoned their 
intentions to learn new knowledge and ended up doing tasks they had already mastered (L14 and L16). Table 2 (in Appendix) summarises the results.

\section{Discussion}

The present study was conducted to shed light on the debate about constructivist learning and its main ingredients: authentic contexts and self-directed learning. Our findings imply that the critiques regarding constructivist learning programmes from both educational sociologists and direct instruction adherents need to be nuanced. Their critiques do not apply to all students alike, with larger differences for knowledge as a system-of-meaning than for knowledge as instrumental. High-level students experienced challenges that brought out the best in them for both forms of knowledge. Medium-level students found authentic contexts and self-directed learning helpful for learning knowledge as instrumental, but not for learning knowledge as a system-of-meaning. Low-level students experienced both help and hinder from authentic learning contexts and found the demands of self-directed learning too high, both for knowledge as instrumental and for knowledge as a system-of-meaning. Table 3 shows an overview of the influences experienced by different students. The experiences reported by our participants offer clues to three factors that lie behind these differences. A first clue points to intrinsic motivation for learning theoretical knowledge. High-level students stood out from the rest by high ambitions and intrinsic motivation to acquire knowledge both as a system-of-meaning and as instrumental. Medium-level students appeared intrinsically motivated to learn knowledge as instrumental but less as a system-of-meaning. Low-level students acknowledged that knowledge is important for a practitioner, but they did not appear intrinsically motivated to learn knowledge as a system-of-meaning. A second clue points to epistemological views on knowledge. The high-level group saw knowledge as self-constructed, reflecting a constructivist viewpoint, in line with the premises of their programme. The other groups held a more positivistic view on knowledge: knowledge is to be derived from experts and taught by teachers. A third clue points to the role of language. Because they did not use formal theoretical language, most participants initially underestimated the extent of their own acquired body of knowledge. This is not an unexpected finding. According to Osmond and O'Connor (2004), social workers are inclined to use informal language when describing what they know. However, it is an important finding because a lack of formal language inhibits social workers from fully functioning at a bachelor's level, that is, to present their work in a professional way, to share knowledge with other professionals, to account for their actions, to examine practice critically, and to negotiate between the different discourses and interests in society (Edwards 1998; Foucault 1980; Irving 2009; Wheelahan, 2010). 
Table 3. Overview of influences on learning theoretical knowledge as experienced by students.

\begin{tabular}{|l|c|c|c|c|}
\hline $\begin{array}{l}\text { Student level } \\
\text { of appraisal of } \\
\text { theoretical } \\
\text { knowledge }\end{array}$ & \multicolumn{2}{|c|}{$\begin{array}{c}\text { Influence of authentic contexts } \\
\text { as experienced by students }\end{array}$} & \multicolumn{2}{|c|}{$\begin{array}{r}\text { Influence of self-directed } \\
\text { learning as experienced by } \\
\text { students }\end{array}$} \\
\cline { 2 - 5 } & $\begin{array}{l}\text { Knowledge as } \\
\text { instrumental }\end{array}$ & $\begin{array}{c}\text { Knowledge as } \\
\text { a system-of- } \\
\text { meaning }\end{array}$ & $\begin{array}{c}\text { Knowledge as } \\
\text { instrumental }\end{array}$ & $\begin{array}{c}\text { Knowledge as } \\
\text { a system-of- } \\
\text { meaning }\end{array}$ \\
\hline High-level & + & + & + & + \\
\hline $\begin{array}{l}\text { High-/ } \\
\text { medium-level }\end{array}$ & + & + & + & + \\
\hline Medium-level & + & - & + & - \\
\hline Low-level & $+/-$ & - & $+/-$ & - \\
\hline
\end{tabular}

Notes: $+=$ positive influence experienced, $-=$ negative influence experienced, + /- = positive and negative influence experienced.

Considering these three factors, intrinsic motivation, epistemological views and language, two opposite hypotheses on student constructivist learning arise. First, constructivist learning is simply too difficult for medium- and low-level students to gain access to knowledge as a system-of-meaning. Second, better alignment to the needs of these students is possible in a constructivist programme. If better alignment is possible, we need to discover to what extent the three identified factors can be influenced and how. Can students' intrinsic motivation be enhanced or is it a rather stable personal trait (Ryan and Deci 2000)? Can students' epistemological views be altered, or do they develop with age and experience (Hofer and Pintrich 2002)? Can students' use of formal language be triggered and stimulated within situated learning? In addition to these questions about students, some issues concerning the social work body of knowledge remain to be addressed: (1) is this knowledge defined well enough to offer the students a consistent and concise system-of-meaning? (2) can students be expected to gain full access to all systems-of-meaning involved in a body of knowledge that is derived from many academic disciplines, as it is in the Netherlands? and (3) how far does this access need to go for these young adults on the brink of entering a complex profession? In a next study, we intend to investigate these last questions in collaboration with work field experts.

\section{References}

Adams, R., Dominelli, L., \& Payne, M. (2002, eds.). Social work: Themes, issues and critical debates. Basingstoke: Palgrave.

Ausubel, D. P. (1963). The psychology of meaningful verbal learning. New York, NY: Grune and Stratton.

Ball, S. J. (2008). The education debate. Bristol: Policy Press.

Beckett, C. (2006). Essential theory for social work practice. London: Sage.

Bereiter, C. (2002). Education and mind in the knowledge age. Mahwah, NJ:

Erlbaum. 
Bruner, J. S. (1966). Toward a theory of instruction. Cambridge: Harvard University Press.

Corbin, J., \& Strauss, A. (2008). Basics of qualitative research. Techniques and procedures for developing grounded theory. Thousand Oaks, CA: Sage.

Cosis Brown, H. (1996). The knowledge base of social work. In A.A. Vass (Ed.), Social work competences. Core knowledge, values and skills, (pp 8-35). London: Sage.

Edwards, R. (1998). Mapping, locating and translating: A discursive approach to professional development. Studies in Continuing Education, 20(1), 23-38.

Eraut, M. (1994). Developing professional knowledge and competence. Abingdon: RoutlegdeFalmer.

Field, J. (2006). Lifelong learning and the new educational order. Stoke on Trent: Trentham.

Foucault, M. (1980). Power/knowledge. Selected interviews and other writings, 1972-1977. New York, NY: Vintage Books.

Hager, P., \& Hodkinson, P. (2009). Moving beyond the metaphor of transfer of learning. British Educational Research Journal, 35(4), 619-38.

Hofer, B. K., \& Pintrich P. R. (2002, Eds.). Personal epistemology: The psychology of beliefs about knowledge and knowing. Mahwah, NJ: Erlbaum.

Irving, A. 2009. Michel Foucault. In Social work theories and methods, ed. M. Gray and S.A. Webb, 43-52. London: Sage.

Kirschner, P.A., J. Sweller, and R. Clark. 2006. Why minimal guidance during instruction does not work: An analysis of the failure of constructivist, discovery, problem-based, experiential and inquiry-based teaching. Educational Psychologist 41, no. 2: 75-86.

Lave, J., and E. Wenger. 1991. Situated learning: Peripheral participation. Cambridge: Cambridge University Press.

Maton, K., and R. Moore, eds. 2010. Social realism, knowledge and the sociology of education. Coalitions of the mind. London: Continuum.

Miles, M.B., and A.M. Huberman. 1994. Qualitative data analysis. An expanded sourcebook. Thousand Oaks, CA: Sage.

Novak, J.D. 2010. Learning, creating and using knowledge. Concept maps as facilitative tools in schools and corporations. New York, NY: Routledge.

Osmond, J. 2005. The knowledge spectrum: A framework for teaching knowledge and its use in social work practice. British Journal of Social Work 35, no. 6: 881900. 
Osmond, J., and I. O'Connor. 2004. Formalizing the unformalized: Practitioners' communication of knowledge in practice. British Journal of Social Work 34, no. 5: 677-92.

Otto, H., A. Polutta, and H. Ziegler, eds. 2009. Evidence-based practice modernising the knowledge based of social work? Leverkusen Opladen: Barbara Budrich.

Parton, N., and P. O’Byrne. 2000. Constructive social work. Towards a new practice. Basingstoke: Palgrave Macmillan.

Piaget, J. 1972. Intellectual evolution from adolescence to adulthood. Human Development 15: 1-12.

Rubin, H.R., and I.S. Rubin. 2005. Qualitative interviewing. The art of hearing data. Thousand Oaks, CA: Sage.

Ryan, R.M., and E.L. Deci. 2000. Intrinsic and extrinsic motivations: Classic definitions and new directions. Contemporary Educational Psychology 25, no. 1: 54-67.

Sectorraad HSAO. 2008. Vele takken, één stam. Kader voor de hogere sociaalagogische opleidingen [Many branches, one trunk. A framework for bachelor's programmes for social workers]. Amsterdam: SWP.

Sfard, Anna. 1998. On two metaphors for learning and the dangers of choosing just one. Educational Researcher 27, no. 2: 4-13.

Simons, P.R.J., J. Van der Linden , and T. Duffy, eds. 2000. New learning. Dordrecht: Kluwer.

Spiro, R.J., and M. DeSchryver. 2009. Constructivism. When it's the wrong idea and when it's the only idea. In Constructivist instruction: Success or failure?, ed. S. Tobias and T.M. Duffy, 106-23. New York, NY: Routledge.

Tobias, S., and T.M. Duffy, eds. 2009. Constructivist instruction. Success or failure. New York, NY: Routledge.

Trevethick, P. 2008. Revisiting the knowledge base of social work: A framework for practice. British Journal of Social Work 38, no. 6: 1212-37.

Tynjälä, P. 2009. Connectivity and transformation in work-related learning theoretical foundations. In Towards integration of work and learning. Strategies for connectivity and transformation, ed. M.-L. Stenström and P. Tynjälä, 11-37. New York, NY: Springer.

Van Bommel, M., H.P.A. Boshuizen, and K. Kwakman. 2012. Appraising the qualities of social work students' theoretical knowledge: A qualitative exploration. Vocations and Learning 5, no. 3: 277-95.

Van den Berg, N., and E. de Bruijn. 2009. Het glas vult zich. Kennis over vormgeving en effecten van competentiegericht beroepsonderwijs; verslag van een review [The glass fills. Knowledge about design and effects of competency 
based vocational education; a review]. Amsterdam: Expertise Centrum Beroepsonderwijs.

Van Ewijk, H. 2010. European social policy and social work. Citizenship-based social work.

London: Routledge.

Van Merriënboer, J.J.G. 1997. Training complex skills. A four component instructional design model for technical training. Englewood Cliffs, NJ: Educational Technology Publications.

Vermunt, J.D., and L. Verschaffel. 2000. Process-oriented teaching. In New learning, ed. P.R.J. Simons, J. Van der Linden, and T. Duffy, 209-25. Dordrecht: Kluwer.

Vygotsky, L.S. 1978. Mind in society. The development of higher psychological processes. Cambridge: Harvard University Press.

Wheelahan, L. 2010. Why knowledge matters in curriculum. A social realist argument. Abingdon: Routledge.

Yin, R.K. 2003. Case study research. Design and methods. Thousand Oaks, CA: Sage. 